\title{
Cloning of an Unstable spoIIA-tyrA Fragment from Bacillus subtilis
}

\author{
By I. MAHLER, ${ }^{1 *}$ R. WARBURG, ${ }^{1}$ D. J. TIPPER ${ }^{2}$ AND \\ H. O. HALVORSON ${ }^{1}$ \\ ${ }^{1}$ Rosenstiel Center for Basic Medical Research, Brandeis University, Waltham, \\ Massachusetts, USA \\ ${ }^{2}$ Department of Molecular Genetics and Microbiology, University of Massachusetts Medical School, \\ Worcester, Massachusetts, USA
}

(Received 7 June 1983; revised 16 August 1983)

\begin{abstract}
A recombinant cosmid clone was isolated from a library created from cosmid pQB79-1 and Bacillus subtilis DNA, and a $15 \mathrm{~kb}$ Bam HI fragment derived from the cloned insert was transferred to the vector pHV33. The recombinant clone, $\mathrm{pRC12}$, was capable of complementing eight auxotrophic markers in the spoIIA-tyrA region of the $B$. subtilis chromosome (map positions 205-210). It also complemented eight of nine markers in the spoIIA locus. The exception, spoIIA176, is the most distal marker from lysine. Although pRC12 failed to complement sporulation defects in spoVA or spoIVA $\left(\right.$ spoIIA $\left.{ }^{+}\right)$strains, subclones of pRC12, lacking a functional spoIIA gene, did complement these mutations. $\mathrm{pRC} 12$ inhibited sporulation in a $s p o^{+} r e c E$ strain, possibly due to the presence of multiple functional spoIIA genes. Both the original cosmid and pRC12 were unstable in Escherichia coli and B. subtilis. Antibiotic selection of the vector resulted in extensive deletion of the insert, while selection for insert function in $B$. subtilis invariably led to loss of the chloramphenicol resistance vector function.
\end{abstract}

\section{INTRODUCTION}

Considerable progress has been made in the cloning of Bacillus subtilis genes, particularly some of the genes involved in the sporulation process (Bonamy \& Szulmajster, 1982; Ferrari et al., 1981; Dubnau et al., 1981; Losick, 1981; Jenkinson \& Mandelstam, 1983). By screening banks for complementation of lys-3 we hoped to obtain the closely linked spoIIA and spoVA loci (Piggot \& Coote, 1976). A fragment which contains a part of the spoIIA locus has been isolated (Liu et al., 1982) from a plasmid bank constructed by Rapoport et al. (1979). The results obtained by Liu et al. (1982) confirmed the complexity of the spoIIA locus suggested by previous mapping studies (Yudkin \& Turley, 1981). spoVA was unique among the loci investigated by Lencastre \& Piggot (1979) in that its expression in the forespore is apparently essential. Isolation of clones including these loci should facilitate investigation of the control of spore gene expression.

A search of existing genomic libraries (Hutchinson \& Halvorson, 1980; Ferrari et al., 1981; Rapoport et al., 1979) did not reveal clones complementing lys-3 or spoIIA26. Aubert et al. (1982) constructed a library of $B$. subtilis genes in the cosmid vector, pQB79-1, obtained by insertion of pC194 into the HindIII site of pHV79 and capable of replication in both Escherichia coli and $B$. subtilis. The advantages of cosmid banks for isolation of large genome segments with consequent simplification of screening are well known, as is their tendency to be unstable in $E$. coli. A copy of the Aubert cosmid library, kindly sent by Dr Rapoport, also lacked clones complementing lys-3 and had clearly undergone extensive deletion during amplification. We decided to create our own cosmid bank in PQB79-1, and to screen it after a minimal number of amplification steps. Testing the bank for biological activity was simplified by the finding that lysates of chloroform-treated cells prepared from recombinant $E$. coli colonies could be used to transform strains of $\boldsymbol{B}$. subtilis (unpublished observations).

Abbreviations: Ap, ampicillin; CAT, chloramphenicol acetyltransferase; $\mathrm{Cm}$, chloramphenicol. 
Table 1. Strains and vectors used

\begin{tabular}{|c|c|}
\hline B. subtilis strains & Genotype \\
\hline $68^{+}$ & Prototroph \\
\hline IS30 & spoIIA12 \\
\hline IS86 & spoIIA1 trpC2 \\
\hline IS79 & spoIIA 37 trpC2 \\
\hline IS80 & spoIIA42 trpC2 \\
\hline IS32 & spollA69 trpC2 \\
\hline IS77 & spoIIA50 thr-5 metB5 \\
\hline IS81 & spoIIA176 trpC2 \\
\hline RC 250 & lys -3 \\
\hline IS80 recE & spoIIA42 recE \\
\hline 5098 & aroC7 $\operatorname{trpC2}$ \\
\hline 5140 & ser- 22 \\
\hline 5139 & $r i b$ \\
\hline SB202 & $\operatorname{trp} C 2$ his $B 2$ aroB2 tyrA \\
\hline SB202 recE & $\begin{array}{l}\operatorname{trpC2} \text { hisB2 aroB2 tyrA recE } 4 \\
\text { rpoB }\end{array}$ \\
\hline MY2016 & lys-1 hisB2 rpoB \\
\hline IS50 & spoVA89 trpC2 \\
\hline IS46 & spoIVA178 phe 112 \\
\hline 5129 & spoIVA67 \\
\hline BD224 & recE thr-5 trpC2 \\
\hline CB2 & recE thr-5 trpC2 rрoB \\
\hline $\mathbf{R} 2$ & spolla26 lys-3 metB10 \\
\hline $\mathbf{R} 2$ rec $E$ & spoIIA26 lys-3 recE \\
\hline R3 & spoIIA4 lys-3 metB10 \\
\hline$E$. coli strains & Genotype \\
\hline $\begin{array}{l}\text { HB101 } \\
\text { SK2881 }\end{array}$ & $\begin{array}{l}\text { hsm hrs gal leuB recA } \\
\mathrm{F}^{-} \text {aroD6 leuC hsdM recA }\end{array}$ \\
\hline Plasmids & Phenotype \\
\hline $\begin{array}{l}\text { pHV33 } \\
\text { pQB79-1 }\end{array}$ & $\begin{array}{l}\operatorname{Ap}^{R} \operatorname{Cm}^{R} \operatorname{Tet}^{R} \\
\operatorname{Ap}^{R} \mathbf{C m}^{R}\end{array}$ \\
\hline
\end{tabular}

\begin{tabular}{|c|}
\hline Origin* \\
\hline ur stock \\
\hline BGSC \\
\hline BGSC \\
\hline BGSC \\
\hline BGSC \\
\hline BGSC \\
\hline BGSC \\
\hline BGSC \\
\hline $\mathrm{R} 2 \times 168$ DNA \\
\hline $\begin{array}{l}\text { (IS80 } \times \text { BD224 recE DNA) } \\
\text { Our stock }\end{array}$ \\
\hline Our stock \\
\hline R. Warburg \\
\hline $\begin{array}{l}\text { J. Pene } \\
(\mathrm{SB202} \times \mathrm{CB} 2 \text { recE DNA) }\end{array}$ \\
\hline H. Jenkinson \\
\hline BGSC \\
\hline BGSC \\
\hline R. Warburg \\
\hline D. Dubnau \\
\hline L. Sonnenshein \\
\hline $\begin{array}{l}\text { D. Dean } \\
(\mathrm{R} 2 \times \mathrm{BD} 224 \operatorname{rec} E \mathrm{DNA})\end{array}$ \\
\hline D. Dean \\
\hline Origin \\
\hline $\begin{array}{l}\text { P. Wensink } \\
\text { S. Kushner }\end{array}$ \\
\hline Origin \\
\hline $\begin{array}{l}\text { G. Rapoport } \\
\text { G. Rapoport }\end{array}$ \\
\hline
\end{tabular}

*Abbreviation: BGSC, Bacillus Genetic Stock Center, Department of Microbiology, The Ohio State University, Columbus, Ohio 43210, USA.

We report here the isolation of an unusual recombinant cosmid clone. The original cosmid and a $15 \mathrm{~kb}$ B. subtilis fragment subcloned from the cosmid into pHV33 (Primrose \& Ehrlich, 1981) complemented many of the markers in the chromosomal region covering map positions 205-210 (spoIIA-tyrA) (Henner \& Hoch, 1980) including almost all spoIIA markers. However, plasmid replication under antibiotic selection in $B$. subtilis or $E$. coli always resulted in extensive loss of insert, while selection for expression of the insert in $B$. subtilis always led to loss of the vector chloramphenicol resistance functions derived from $\mathrm{pC} 194$.

\section{METHODS}

Bacterial strains and vectors. The strains and vectors used during this study are listed in Table 1 . For construction of most recE strains, DNA from $B$. subtilis BD224 thr-5 trpC2 recE4 was used to transform a recipient strain to prototrophy for an appropriate marker. SB202 recE was constructed using DNA from strain CB2. Colonies were screened for sensitivity to $0.05 \mu \mathrm{g}$ mitomycin $\mathrm{C} \mathrm{ml}^{-1}$ to determine the RecE phenotype.

Growth of bacteria. Escherichia coli and $B$. subtilis cells were grown on $\mathrm{LB}$ medium containing $5 \mathrm{~g} \mathrm{NaCl}, 5 \mathrm{~g}$ yeast extract (Difco) and $10 \mathrm{~g}$ tryptone (Difco) $\mathrm{l}^{-1}$. DSM medium contained ( ${ }^{-1}$ ): nutrient broth (Difco), $8 \mathrm{~g} ; \mathrm{MgSO}_{4}$, $0.25 \mathrm{~g} ; \mathrm{KCl}, 1 \mathrm{~g} ; \mathrm{MnCl}_{2}, 1.98 \mathrm{mg} ; \mathrm{FeSO}_{4}, 0.03 \mathrm{mg} ;$ and $\mathrm{CaCl}_{2}, 111 \mathrm{mg} .2 \times \mathrm{DSM}$ contained $16 \mathrm{~g}$ nutrient broth but was otherwise identical to DSM. Auxotrophic markers were checked on minimal glucose medium (Bott \& Wilson, 1968) supplemented with $2 \mathrm{~g}$ of appropriate amino acid assay medium $1^{-1}$ (Difco). LB-Ap medium contained $100 \mu \mathrm{g}$ Ampicillin (Ap) $\mathrm{ml}^{-1}$, and $\mathrm{LB}-\mathrm{Cm}, 5 \mu \mathrm{g}$ chloramphenicol $(\mathrm{Cm}) \mathrm{ml}^{-1}$.

Transformation. Cells of $E$. coli were made competent for DNA uptake as described by Wensink et al. (1974). Competent $B$. subtilis cells were prepared by the method of Bott \& Wilson (1968). Transformants were selected on LB-Ap or LB-Cm plates, or on minimal assay plates. To test for transformation of Spo ${ }^{+}$markers, $0 \cdot 1 \mathrm{ml}$ of the transformation suspension was inoculated into $1 \mathrm{ml} 2 \times \mathrm{DSM}$ broth. The culture tubes were incubated at $37^{\circ} \mathrm{C}$ 
with aeration for $20 \mathrm{~h}$, heated at $80^{\circ} \mathrm{C}$ for $20 \mathrm{~min}$ and $0.1 \mathrm{ml}$ plated on DSM plates. Spores survived the heat treatment and gave rise to sporogenous opaque pigmented colonies on DSM.

DNA extraction. Plasmid DNA from E. coli was prepared by the method of Wensink et al. (1974) and plasmid DNA from B. subtilis by the method of Tanaka \& Sakaguchi (1978). Chromosomal DNA was prepared as described by Marmur (1961).

For determining the plasmid copy number, cells in $200 \mathrm{ml}$ minimal glucose medium were labelled with [methyl${ }^{3} \mathrm{H}$ ]thymidine (13 $\mathrm{Ci} \mathrm{m}^{-1} ; 481 \mathrm{GBq} \mathrm{m}^{-1}$; New England Nuclear) by the method of Lovett \& Bramucci (1974). $\mathrm{CsCl}$-ethidium bromide centrifugation was carried out at $100000 \mathrm{~g}$ for $24 \mathrm{~h}$. Fractions were collected, precipitated with $5 \%(w / w)$ trichloroacetic acid, and counted.

Enzymes and electrophoresis. Restriction enzymes and T4 ligase were purchased from either New England Biolabs or Boehringer Mannheim. Buffers were prepared according to the manufacturer's specification. DNA samples were hydrolysed for $30 \mathrm{~min}$ at $37^{\circ} \mathrm{C}$, heated at $69^{\circ} \mathrm{C}$ for $3 \mathrm{~min}$ and chilled. Ligation was carried out overnight at $15{ }^{\circ} \mathrm{C}$, unless otherwise stated. Samples were electrophoresed in horizontal gels of $0.8 \%$ agarose in Tris/acetate buffer (pH 7.8) (20 mM-Tris, 40 mM-sodium acetate, 1 mM-EDTA). Gels were stained with ethidium bromide and DNA bands were visualized with UV light and photographed. For extraction of DNA bands from gels, low melting agarose (SEA Plaque, Marine Colloids Div., FMC Corporation) was used and the bands excised after visualization with a $300 \mathrm{~nm}$ UV source (Fotodyne).

Construction of a cosmid colony bank of $B$. subtilis DNA in E. coli. (a) Chromosomal DNA $\left(3.6 \mathrm{mg} \mathrm{ml}^{-1}\right)$ from B. subtilis 168 was prepared and partially cut with Sau3A (Biolabs) as described by Karn et al. (1980) using $50 \mu l$ aliquots of DNA $(180 \mu \mathrm{g})$ with $0 \cdot 4,0 \cdot 8,2,4$ or 8 units of enzyme at $37^{\circ} \mathrm{C}$ for $30 \mathrm{~min}$. After heat inactivation $\left(65^{\circ} \mathrm{C}\right.$ for $10 \mathrm{~min}$ ) the DNA solutions were mixed, extracted once with phenol (saturated with $10 \mathrm{mM}-\mathrm{Tris} / \mathrm{HCl} \mathrm{pH} 8$ ) and then with ether; sodium acetate was added to $0.3 \mathrm{M}$ and the DNA precipitated with ethanol. The resulting DNA was size fractionated through four consecutive sucrose gradients $(15-30 \%)$ and fractions with a molecular weight of 35-40 kb taken, precipitated with ethanol and resuspended in $10 \mathrm{mM}$-Tris, $1 \mathrm{mM}$-EDTA (TE) to $400 \mu \mathrm{g} \mathrm{ml} \mathrm{m}^{-1}$.

(b) Amplified cosmid pQB79-1 (Aubert et al., 1982) DNA was prepared and purified by isopycnic centrifugation through $\mathrm{CsCl} .20 \mu \mathrm{g}$ was digested to completion with 20 units of $\mathrm{BamHI}(\mathrm{BRL})$ for $1 \mathrm{~h}$ at $37^{\circ} \mathrm{C}$ and, following the methods recommended by BRL, treated with bacterial alkaline phosphatase (BRL; 680 units) for $1 \mathrm{~h}$ at $65^{\circ} \mathrm{C}$. The phosphatase was destroyed by hydrolysis with proteinase $\mathrm{K}(20 \mu \mathrm{g})$ for $10 \mathrm{~min}$ at $37^{\circ} \mathrm{C}$ and the solution extracted twice with Tris-saturated phenol and once with ether. The DNA was precipitated twice with ethanol and finally resuspended in TE to $200 \mu \mathrm{g} \mathrm{ml}^{-1}$. Without phosphatase treatment, very few of the $\mathrm{Ap}^{R}$ colonies resulting from ligation contained inserted DNA.

(c) Ligation: $5 \mu \mathrm{l}$ vector DNA $(1 \mu \mathrm{g})$ was mixed with $1 \mu \mathrm{l}$ chromosomal DNA $(0.4 \mu \mathrm{g})$ and $0.7 \mu 110 \times 1$ ligase buffer containing 100 cohesive end units of ligase (Collaborative Research) and incubated at $4{ }^{\circ} \mathrm{C}$ for $18 \mathrm{~h}$. It was then heated to $70^{\circ} \mathrm{C}$ for $10 \mathrm{~min}$ and cooled on ice.

(d) Packaging: $2.5 \mu$ aliquots of ligated DNA were packaged as described by Hohn \& Murray (1977) and $100 \mu \mathrm{l}$ aliquots of the resulting phage used to transfect $2 \times 10^{8}$ cells of $E$. coli strain SK2881 grown in LB containing $4 \mathrm{mg}$ maltose $\mathrm{ml}^{-1}$ and $10 \mathrm{mM}-\mathrm{MgSO}_{4}$. After $30 \mathrm{~min}$ incubation at $37^{\circ} \mathrm{C}$ in $\mathrm{LB}$ broth, the cells were spread on LB-Ap plates and incubated at $37^{\circ} \mathrm{C}$ for $18 \mathrm{~h}$. Individual colonies were grown for $18 \mathrm{~h}$ in $5 \mathrm{ml} \mathrm{LB}$-Ap broth; cosmid DNA was prepared from $1.5 \mathrm{ml}$ of this culture as described by Holmes \& Quigley (1981) and analysed on minigels. Many of the colonies tested contained cosmids with inserts greater than $30 \mathrm{~kb}$.

$(e)$ Preparation of lysates: three drops of chloroform were added to the residual $3.5 \mathrm{ml}$ of the above cultures and vortexed. The chloroform-treated cultures were stored at $4{ }^{\circ} \mathrm{C}$ and represented a crude preparation of DNA. $5 \mu$ of such a solution contained a saturating level of DNA in transformation experiments with competent $E$. coli or $B$. subtilis cells. These lysates contain both cosmid and chromosomal DNA, however, DNA similarly prepared from cells of $E$. coli SK2881 was not able to transform competent cells of either $E$. coli SK2881 or B. subtilis for any of the markers tested. Hence assay of these lysates for transforming activity provided a simple method of screening the bank for the markers of interest; the solutions were active over a period of at least two months.

\section{RESULTS}

\section{Lysate of cosmid clone 12 contains the lys-3 and spollA26 genes}

The cosmid bank, isolated under ampicillin selection in $E$. coli SK2881, consisted of 84 colonies. These were grown in LB-Ap broth $(5 \mathrm{ml})$ as individuals and in 7 pools of 12 colonies. Each culture was used to make a chloroform lysate $(3.5 \mathrm{ml})$ and a plasmid preparation (from $1.5 \mathrm{ml}$ ). Individual lysates were tested for their ability to transform $B$. subtilis strain R2 (lys-3 spoIIA26) to lysine prototrophy. $25 \mu \mathrm{l}$ of pool 1 (colonies 1-12) yielded about $20 \mathrm{Lys}^{+}$colonies and the individual lysate $12(25 \mu \mathrm{l})$ yielded about $10^{3} \mathrm{Lys}^{+}$colonies. Within $72 \mathrm{~h}$ at $37^{\circ} \mathrm{C}$, 
Table 2. Transformation of $B$. subtilis strains $R 2^{+}$and $R 2$ recE with lysate $12 \mathrm{DNA}$

\begin{tabular}{|c|c|c|c|}
\hline \multirow[b]{2}{*}{ Recipient Strain } & \multicolumn{3}{|c|}{$\begin{array}{l}\text { No. transformants } \mathrm{ml}^{-1} \\
\text { with selection:* }\end{array}$} \\
\hline & Lys-3+ & SpollA26 ${ }^{+} \dagger$ & $\mathrm{Cm}^{\mathrm{R}}$ \\
\hline R2 & $\begin{array}{c}2.1 \times 10^{3} \\
\left(60 \% \mathrm{Spo}^{+}\right) \\
\left(0 \% \mathrm{Cm}^{\mathrm{R}}\right)\end{array}$ & $\begin{array}{c}9 \times 10^{2} \\
\left(100 \% \mathrm{Lys}^{+}\right) \\
\left(0 \% \mathrm{Cm}^{\mathrm{R}}\right)\end{array}$ & $\begin{array}{l}5.5 \times 10^{3} \\
\left(0 \% \mathrm{Lys}^{+}\right) \\
\left(0 \% \mathrm{Spo}^{+}\right)\end{array}$ \\
\hline R2 recE & 0 & $\begin{array}{l}4.9 \times 10^{2} \\
\left(0 \% \mathrm{Lys}^{+}\right) \\
\left(0 \% \mathrm{Cm}^{\mathrm{R}}\right)\end{array}$ & $\begin{array}{r}1 \times 10^{3} \\
\left(0 \% \mathrm{Lys}^{+}\right) \\
\left(0 \% \mathrm{Spo}^{+}\right)\end{array}$ \\
\hline
\end{tabular}

* Numbers in parentheses refer to results of screening of selected transformants by replica plating.

$\dagger$ Estimate of transforming activity of heat selected Spo ${ }^{+}$cells.

approximately $60 \%$ of the $\mathrm{Lys}^{+}$colonies produced pigment and a large number of phase-bright spores (Table 2). spoIIA26 had a reversion frequency of less than $10^{-8}$.

Lysates of the seven pools were also tested for their ability to transform cells of strain R2 to $\mathrm{Spo}^{+}$by selection for heat resistance following growth in DSM at $37^{\circ} \mathrm{C}$ for $18 \mathrm{~h}$. Only approximate estimates of transforming activity can be derived by this procedure. However, with stable mutations such as spoIIA26 the results were unambiguous. Pool 1 and lysate 12 again gave $\mathrm{Spo}^{+}$transformants. All were Lys ${ }^{+}$(Table 2).

When the recombination-deficient strain $\mathrm{R} 2$ recE was used as the recipient, $\mathrm{Spo}^{+}$heatresistant colonies were still produced, but no Lys $^{+}$prototrophs were isolated (Table 2). Since complementation of the $r e c E$ recipient presumably requires an intact, functional plasmid-borne gene, spoIIA26 is intact but lys-3 is not.

\section{Segregation of antibiotic resistance}

None of the Spo ${ }^{+}$transformants of strain $\mathrm{R} 2$ recE nor any of the $\mathrm{Spo}^{+}$or $\mathrm{Lys}^{+}$transformants of strain R2 were chloramphenicol-resistant (Table 2). It appeared as if the transformants of these strains had lost the functional chloramphenicol acetyltransferase (CAT) gene normally present in the pC194 segment of pQB79-1. Lysate 12 transformed E. coli SK2881 to $\mathrm{Cm}^{\mathrm{R}}$ or $\mathrm{Ap}^{\mathrm{R}}$ or $B$. subtilis strains $\mathrm{R} 2$ and $\mathrm{R} 2$ recE to $\mathrm{Cm}^{\mathrm{R}}$ but none of the $B$. subtilis transformants were either $\mathrm{Spo}^{+}$or $\mathrm{Lys}^{+}$(Table 2). No Spo ${ }^{+} \mathrm{Cm}^{\mathrm{R}}$ transformants of $\mathrm{R} 2$ recE were obtained by simultaneous selection, consistent with the apparent loss of a functional plasmid CAT gene in transformants selected for the spoIIA26 marker.

\section{Construction of $p R C 12$}

Attempts at isolating plasmid DNA from recE Spo ${ }^{+}$transformants gave only a single band of chromosomal DNA which suggested a very low plasmid copy number. To allow chloramphenicol selection of plasmid DNA carrying the lys-3 and spoIIA26 markers, cosmid 12 DNA was cut with BamHI and ligated to BamHI-cut DNA of pHV33. Following transformation of strain R2 recE, growth in DSM containing chloramphenicol and selection for heat resistance, a single $\mathrm{Cm}^{\mathrm{R}} \mathrm{Spo}^{+}$colony was isolated. Plasmid DNA isolated from this strain, following digestion with BamHI. showed a large amount of the pHV33 vector and a small amount of a $15 \mathrm{~kb}$ insert (Fig. 1).

This recombinant plasmid, $\mathrm{pRC12}$, was separated from pHV33 by electrophoresis in low melting point agarose. The excised top band (Fig. 1, lane 3) was eluted from the melted gel and used to transform cells of strain $\mathrm{R} 2$ and $\mathrm{R} 2 \mathrm{recE}$. The results were identical to those obtained with cosmid 12 DNA (Table 2); no $\mathrm{Cm}^{\mathrm{R}} \mathrm{Lys}^{+}$or $\mathrm{Cm}^{\mathrm{R}} \mathrm{Spo}^{+}$colonies could be isolated. Initial success in selection of the $\mathrm{Cm}^{\mathrm{R}} \mathrm{Spo}^{+}$transformant yielding $\mathrm{pRC12}$ was presumably due to cotransformation by pHV33. Once again, the cloned insert appeared to have segregated from the vector CAT gene. 


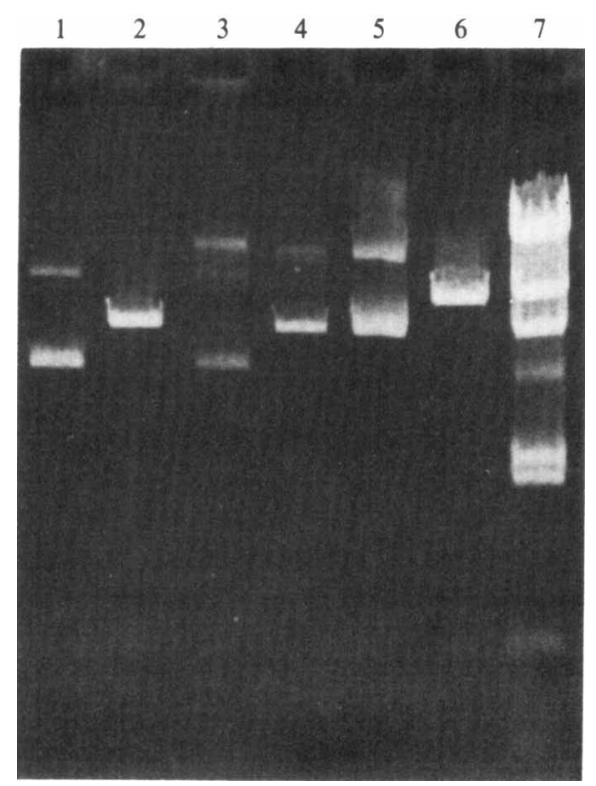

Fig. 1. Electrophoretic pattern of pRC12 DNA. CsCl-ethidium bromide-purified pRC12, plasmid vector, pHV33 and cosmid vector pQB79-1 DNA were digested with BamHI and analysed by agarose gel electrophoresis. Lane 1, pHV33; lane 2, pHV33 digested with BamHI; lane 3, pRC12; lane 4, pRC12 cut with BamHI; lane 5, cosmid pQB79-1; lane 6, pQB79-1 digested with BamHI; lane 7, molecular size markers - lambda DNA digested with HindIII.

\section{Copy number of $p R C 12$}

pRC12 could only be selected in strain $\mathrm{R} 2$ recE by complementation of spoIIA26, and its apparent low copy number could be a consequence of a gene dosage effect on expression of this locus. We therefore measured the plasmid to total DNA ratios in $\mathrm{Spo}^{+}$transformants of $\mathrm{R} 2$ recE ( $\mathrm{pRC12}$ ) labelled with $\left[\right.$ methyl $\left.{ }^{3} \mathrm{H}\right]$ thymidine. Two peaks of DNA were observed. The major peak contained chromosomal DNA capable of transforming only $\mathrm{Rec}^{+}$strains for a variety of auxotrophic markers. The minor peak transformed cells of $\mathrm{R} 2$ to $\mathrm{Lys}^{+}$and $\mathrm{Spo}^{+}$and $\mathrm{R} 2$ recE to $\mathrm{Spo}^{+}$only. It contained approximately $1 \%$ of the radioactivity of the total DNA extracted from exponential phase cells. When an aliquot of the same culture was grown for an additional $12 \mathrm{~h}$ into stationary growth phase, only $0.6 \%$ of the radioactivity remained in the plasmid fraction. The size of pRC12 was estimated as $22 \mathrm{~kb}$ (Fig. 1). Using the value of $3000 \mathrm{~kb}$ for the B. subtilis chromosome (Kavenoff, 1972) the copy number of pRC12 appeared to be about one per cell. As the transformed cells replicated in the absence of selective pressure, the chimeric plasmid decreased to less than one copy per cell.

\section{Genetic markers carried by $p R C 12$}

pRC12 and the original cosmid 12 lysate were tested for genetic markers adjacent to spoIIA and lys-3. The spoIIA locus (Piggot \& Coote, 1976) contains a number of mutations which may lie within two genes (Liu et al., 1982). Several of these have been mapped recently (Yudkin \& Turley, 1981; Lazdin, 1980) (Fig. 2). pRC12 DNA transformed all the mutations with the exception of spoIIA176. spoIIA63 was not tested. $\mathrm{Spo}^{+}$transformants were obtained from spoII 42 but not from a spoIIA42 recE strain. Duplicate transformation experiments carried out with a lys-3 $\mathrm{spo}^{+}$recipient strain using $1 \mu \mathrm{g} \mathrm{DNA} \mathrm{ml}{ }^{-1}$ isolated from strains $1 \mathrm{~S} 30$ (IIA 12), $1 \mathrm{~S} 77$ (IIA50), and 1S81 (IIA176) indicated that IIA176 is less closely linked to lys-3 (41\%) than either IIAI $2(57 \%)$ or IIASO (56\%). This suggested that spoIIAI76 maps to the left of spoIIASO (Fig. 2), further from lys than any known spoIIA marker, apparently in a region not complemented by pRC12. 

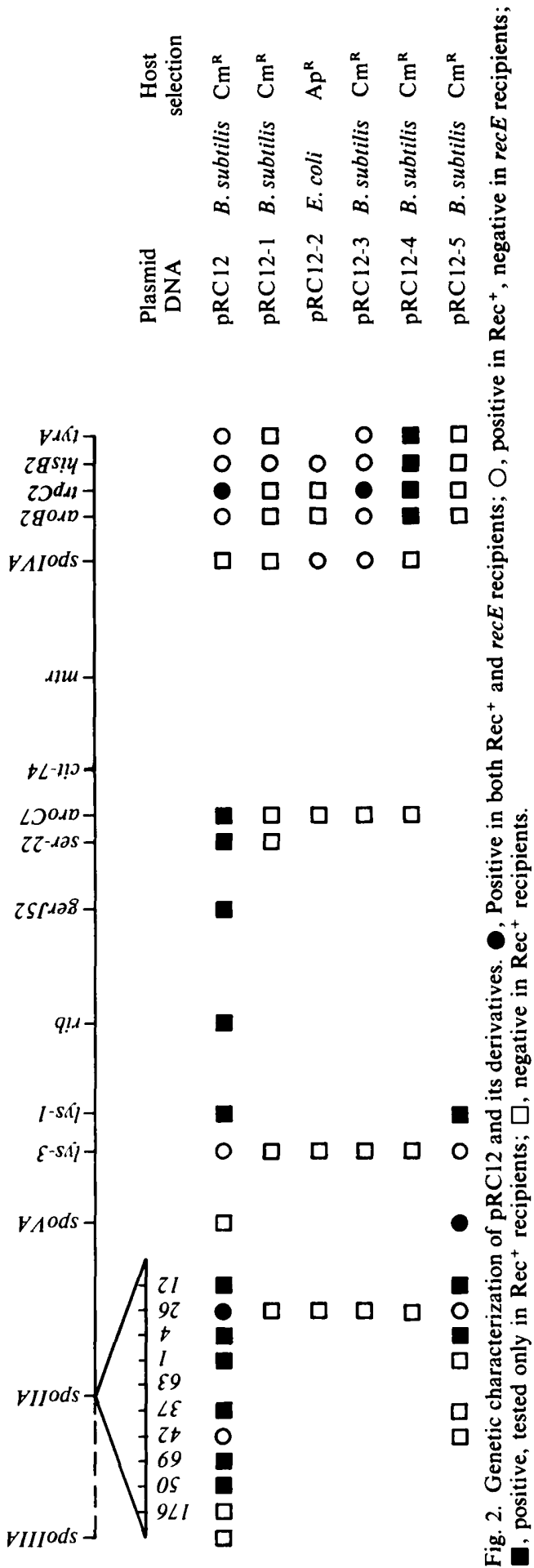
Table 3. Transformation using $p R C 12$ and chromosomal DNA

\begin{tabular}{|c|c|c|c|}
\hline \multirow[b]{2}{*}{ Recipient strains } & \multirow[b]{2}{*}{ Selection } & \multicolumn{2}{|c|}{$\begin{array}{c}\text { No. transformants } \mathrm{ml}^{-1} \\
\text { per } \mu \mathrm{g} \text { DNA preparation: }\end{array}$} \\
\hline & & pRC12 & 168 \\
\hline $\mathbf{R} 2$ & $\begin{array}{l}\text { spolla } 26 \\
\text { lys-3 }\end{array}$ & $\begin{array}{l}2000 \\
3000\end{array}$ & $\begin{array}{l}2500 \\
2900\end{array}$ \\
\hline $\mathrm{R} 2 \mathrm{rec} E$ & $\begin{array}{l}\text { spoIIA } 26 \\
\text { lys-3 }\end{array}$ & $\begin{array}{r}600 \\
0\end{array}$ & $\begin{array}{l}0 \\
0\end{array}$ \\
\hline IS30 & spoIIA 12 & 1820 & 4100 \\
\hline $\mathbf{R} 3$ & spoIIA4 & 500 & 12000 \\
\hline IS86 & spoIIAI & 410 & 9500 \\
\hline IS79 & spoIIA 37 & 300 & 8000 \\
\hline IS80 & spoIIA42 & 790 & 3800 \\
\hline IS 32 & SpoIIA69 & 1000 & 6000 \\
\hline IS77 & spoIIA50 & 300 & 600 \\
\hline IS81 & spoIIA176 & 0 & 300 \\
\hline MY2016 & lys -1 & 25000 & 25000 \\
\hline 5139 & rib & 30000 & 30000 \\
\hline 5098 & aroc7 & 160 & 2500 \\
\hline 5140 & ser-22 & 100 & 3500 \\
\hline SB202 & aroB2 & 3000 & 14000 \\
\hline & $\operatorname{trp} C 2$ & 800 & 12000 \\
\hline & hisB2 & 8000 & 10000 \\
\hline & tyrA & 8000 & 10000 \\
\hline $\mathrm{SB} 202$ recE & aroB2 & 0 & 0 \\
\hline & $\operatorname{trp} C 2$ & 400 & 0 \\
\hline & hisB2 & 0 & 0 \\
\hline & $\operatorname{tyr} A$ & 0 & 0 \\
\hline BD224 recE & $t h r-5$ & 0 & 0 \\
\hline R3 & met & 0 & 25000 \\
\hline
\end{tabular}

- The numbers of transformants are well above the background of spontaneous reversion, which has been subtracted.

pRC12 transformed strain MY2016 lys-1 to $\mathrm{Lys}^{+}$, as well as the following auxotrophic mutations to prototrophy in $\operatorname{Rec}^{+}$backgrounds: $\operatorname{rib}, \operatorname{aroC}, \operatorname{ser}-22, \operatorname{aroB} 2, \operatorname{trp} C 2$, hisB2, and $\operatorname{tyr} A$ (Fig. 2, Table 3). No markers outside of the spoIIA-tyrA region were transformed with the DNA (Table 3) indicating that transforming activity was not due to contaminating chromosomal DNA. In recE backgrounds, $\operatorname{trp} C 2$ but not $l y s-3, \operatorname{tyr} A, \operatorname{aroB} 2$, or his $B 2$ were complemented (Table 3 ). Thus, $\operatorname{trp} C 2$ was the only auxotrophic marker tested which expressed on the plasmid.

\section{Antibiotic selection of $p R C 12$ leads to loss of insert and biological activity}

Lysate 12 or pRC12 DNAs were transformed into E. coli $\mathrm{HB} 101$ and $B$. subtilis strains and the transformed cells selected with either ampicillin or chloramphenicol. The molecular species isolated ( $\mathrm{pRC1} 2-1,-2$, etc.) were smaller and had lost complementation activity for most of the genetic markers shown in Fig. 2. pRC12-1 isolated from $B$. subtilis under $\mathrm{Cm}^{\mathrm{R}}$ selection, retained transforming activity for hisB2 (Fig. 2). pRC12-2, isolated from $E$. coli under $A^{\mathrm{R}}$ selection, also retained transforming activity only for the hisB2 auxotrophic marker (Fig. 2). pRC12-3, isolated from $B$. subtilis under $\mathrm{Cm}^{\mathrm{R}}$ selection, retained transforming activity for $\operatorname{trp} C 2$, hisB2, and $t y r A$ and still complemented only $\operatorname{trp} C 2$ in strain SB202 recE(Fig. 2). The Trp ${ }^{+}$transformants of this strain were all $\mathrm{Cm}^{\mathrm{s}}$. The smallest of these deleted plasmids, pRC12-4, obtained from $B$. subtilis $\left(\mathrm{Cm}^{\mathrm{R}}\right.$ selection) appeared to be of the same size as pHV33 (Fig. 3). pRC12-4 DNA transformed strain SB202 $\mathrm{rec}^{+}$producing approximately $100 \mathrm{Trp}^{+}, \mathrm{His}^{+}$or $\mathrm{Tyr}^{+}$colonies $\mathrm{ml}^{-1}$ $(\mu \mathrm{g} \text { DNA })^{-1}$.

pRC12-5, a $10 \mathrm{~kb}$ molecule (Fig. 3) also obtained from $B$. subtilis under $\mathrm{Cm}^{\mathrm{R}}$ selection, lacked all markers in the aro $C-t y r A$ region, but retained the ability to correct lys- 1 and lys-3 only in $\mathrm{Rec}^{+}$strains (Fig. 2). pRC12-5 DNA also corrected the sporulation defects in $\mathrm{Rec}^{+}$strains caused by mutations spoIIA12, spoIIA26, and spoIIA4 in the spoIIA locus, but, unlike pRC12 


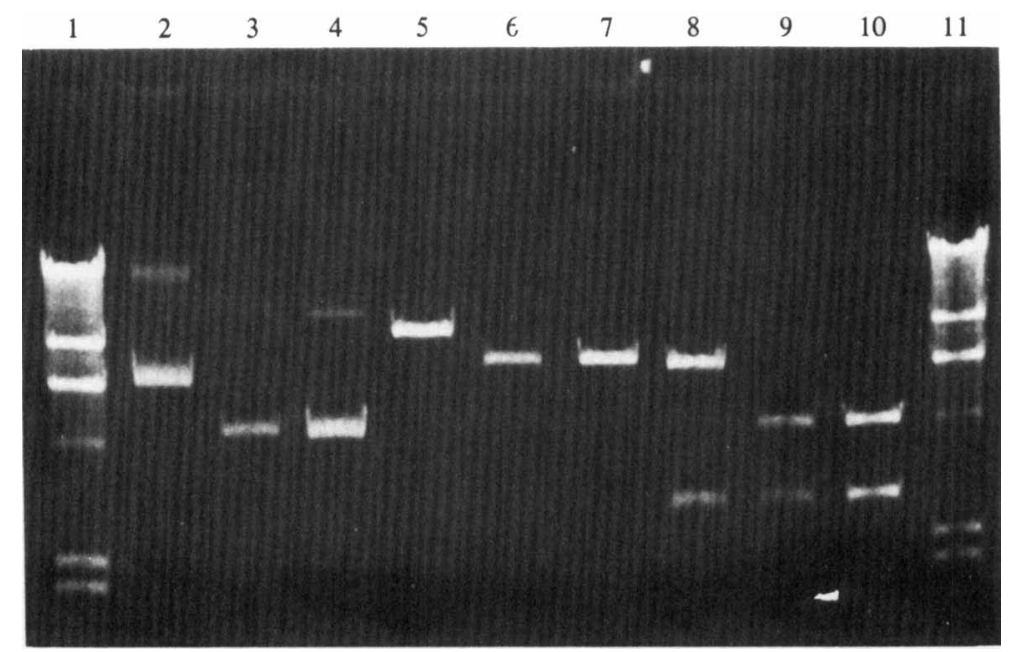

Fig. 3. Electrophoretic pattern of pRC12-4 and pRC12-5 DNA. CsCl-ethidium bromide-purified DNAs of subclones pRC12-4, pRC12-5 and pHV33 were digested with EcoRI and HindIII and analysed by agarose gel electrophoresis. Lane 1, lambda DNA digested with HindIII ; lane 2, pRC12-5; lane 3, pRC12-4; lane 4, pHV33; lane 5, pRC12-5 cut with EcoRI; lane 6, pRC12-4 cut with EcoRI; lane 7, pHV33 cut with EcoRI; lane 8, pRC12-5 cut with HindIII; lane 9, pRC12-4 cut with HindIII; lane 10, pHV33 cut with HindIII; lane 11, lambda DNA cut with HindIII (molecular size markers).

DNA, no longer complemented spoIIA1, spoIIA37, spoIIA42, or spoIIA50 (Fig. 2). pRC12-5 also failed to transform $\mathrm{R} 2 \mathrm{rec} E$ to $\mathrm{Spo}^{+}$suggesting that this subclone no longer carried a functional spoIIA gene.

\section{pRC12-5 carries an intact spoVA89 gene; multiple functional spoIIA genes may prevent sporulation}

Both spoVA89 and spoVA89 recE strains were transformed to $\mathrm{Spo}^{+}$by $\mathrm{pRC12-5}$ DNA. All transformants were $\mathrm{Cm}^{\mathrm{s}}$. In contrast, neither lysate 12 nor $\mathrm{pRC} 12$ would transform either strain to $\mathrm{Spo}^{+}$. Since $\mathrm{pRC12-5}$ was derived from pRC12, either the latter contained a cryptic spoVA89 gene, only expressed following deletion to produce pRC12-5, or an intact spoVA89 gene was acquired during production of $\mathrm{pRC12-5}$ by replication of $\mathrm{pRC1} 2$ in $\mathrm{Spo}^{+} \mathrm{Rec}^{+} B$. subtilis cells. If multiple functional spoIIA locus genes suppress sporulation, then loss of such functional genes during isolation of $\mathrm{pRC12}-5$ might be responsible for unmasking a functional plasmid spoVA gene. To test this possibility, pRC12 was transformed into SB202 recE (a Spo ${ }^{+}$strain). $\operatorname{Trp}^{+}$ transformants were obtained [200 ( $\mu \mathrm{g}$ DNA $\left.)^{-1}\right]$. All were $\mathrm{Cm}^{\mathrm{s}}$ and $78 \%$ were $\mathrm{Spo}^{-}$.

\section{pRC12-2 and pRC12-3 carry spoIVA (178 and 67)}

Because the functional spoIIA gene on pRC12 might also mask complementation of the spoIVA locus located near aroB2 (Fig. 2) we tested subclones of $\mathrm{pRC12}$, which were deleted for spoIIA but retained ability to complement auxotrophic markers adjacent to spoIVA, for ability to complement spoIVA markers. Although pRC12-1 and pRC12-4 lacked such activity, pRC12-2 and $\mathrm{pRC12-3}$ DNAs transformed $\mathrm{Rec}^{+}$but not recE strains of spoIVA178 and spoIVA67 to Spo ${ }^{+}$ (Fig. 2). As with spoVA89, no such transforming activity could be detected in lysate 12 or pRC12 DNAs.

\section{DISCUSSION}

Aubert et al. (1982) found that recombinant clones in vector pQB79-1 yielded chiefly $\mathrm{Cm}^{\mathrm{s}}$ transformants of $\operatorname{Rec}^{+} B$. subtilis strains if the selection was for an auxtrophic marker, but yielded $\mathrm{Cm}^{\mathrm{R}}$ transformants of $r e c E$ strains regardless of the selective procedure. Similarly Liu et 
al. (1982) found that pHM-2, carrying part of the spoIIA locus in pHV33, was stable in recE strains under selection for $\mathrm{Cm}^{\mathrm{R}}$, so that $\mathrm{Cm}^{\mathrm{R}}$ transformants of spoIIA50, spoIIA69, or spoIIA42 retained the spoIIA defect in the chromosome but were phenotypically $\mathrm{Spo}^{+}$because of expression of the plasmid-encoded spoIIA gene.

Our finding that lysate 12 produced only $\mathrm{Spo}^{+} \mathrm{Cm}^{\mathrm{S}}$ transformants of strain $\mathrm{R} 2 \mathrm{rec} E$ suggested that the CAT gene on the $\mathrm{pC} 194$ component of $\mathrm{pQB79-1}$ had been damaged during construction or replication of the cosmid bank. However, transformants of strain $\mathrm{R} 2$ recE by $\mathrm{pRC12}$, derived by transfer of a $15 \mathrm{~kb}$ portion of the cosmid 12 insert into pHV33, again fell into two classes: $\mathrm{Cm}^{\mathrm{R}}$ colonies lacking insert or $\mathrm{Spo}^{+}$colonies which were $\mathrm{Cm}^{\mathrm{S}}$. In addition, all $\mathrm{Trp}^{+}$ transformants of strain SB202 recE were also $\mathrm{Cm}^{\mathrm{S}}$, as were all transformants of the $\mathrm{Rec}^{+}$strains carrying the auxotrophic markers indicated in Fig. 2.

The subclones resulting from the deletion of $\mathrm{pRC} 12$ isolated under $\mathrm{Cm}^{\mathrm{R}}$ selection in $E$. coli or $B$. subtilis respectively, behaved similarly: selection for sporulation or auxotrophic markers gave only $\mathrm{Cm}^{\mathrm{s}}$ transformants. The reason for the instability of vector CAT gene expression when selecting for expression of insert is not known.

Dean (1984) mentioned that nucleotide sequences near lys might be deleterious in high copy number. The lys gene has been cloned in bacteriophage vectors (Yamare et al., 1982; Jenkinson \& Mandelstam, 1983), and more than one functional copy of this gene for meso-diaminopimelate decarboxylase might lead to a lethal imbalance in cell wall biosynthesis. However, the isolation. of deleted pRC12 molecules, such as pRC12-3 which cannot complement either lys-3 or lys-1 and behave like $\mathrm{pRC12}$, renders this possibility unlikely. The suggestion that the basic instability of pRC12 results from its size $(22 \mathrm{~kb})$ may account for the appearance of partially deleted plasmids which carry small inserts but does not explain why these, like pRC12, cannot be amplified by $\mathrm{Cm}$ selection.

The markers in the spoIIA-tyrA region complemented by $\mathrm{pRC} 12$ cover a region estimated, by recombination frequency, to be at least $40-50 \mathrm{~kb}$ (Henner \& Hoch, 1980). One of us ( $R$. Warburg, unpublished observations) has isolated a $15 \mathrm{~kb}$ fragment of contiguous $B$. subtilis DNA, carrying aroC and ser-22, but lacking any of the adjacent markers indicated in Fig. 2. In addition, only the spoIIA26, $\operatorname{trpC} 2$ and possibly the spoVA89 genes are known to be functionally intact on $\mathrm{pRC12}$, while hisB2, tyrA, lys-3, lys-1, and aroB2 fail to express in recE strains. Extensive multiple deletion events may have occurred during replication of cosmid 12 in E. coli, which might account for the plasmid's basic instability.

The properties of pHM2, a plasmid carrying the spoIIA markers 50 to 42 (Liu et al., 1982), strongly suggested the presence of at least two genes in this locus, with a boundary between markers 42 and 37 . The ability of $\mathrm{pRC} 12$ to complement all of the known spoIIA markers except spoIIA176, and its ability to transform spoIIA26 recE but not spoIIA42 recE indicated that pRC12 contained at least one functional spoIIA gene absent in pHM2.

Cloned spo markers in phage or plasmid vectors transformed into $\mathrm{Spo}^{-} \mathrm{recE}$ host cells allows analysis of dominance-recessive relationships and tests the effect of dosage of normal genes on sporulation phenotype. To date, mutations in all $B$. subtilis spo loci tested are recessive, including spoOH (Dubnau et al., 1981), spoOB, spoOF (Kawamura et al., 1981 ; Bonamy \& Szulmajster, 1982), spoVG, spoVC (Losick, 1981), spoIIA (Liu et al., 1982) and spoIIIB (Jenkinson \& Mandelstam, 1983). Our data indicate that chromosomal mutations in the genes defined by spoIIA26 and spoVA89 are also recessive to plasmid-encoded normal genes. While multiple copies of many sporulation genes seem to be compatible with sporulation (Kawamura et al., 1981; Bonamy \& Szulmajster, 1982), the detrimental effect (on normal sporulation) of multiple spoOF genes (Kawamura et al., 1981) and an amplified sporulation promoter (Banner, 1980) has been described. The suppression of sporulation of strain SB202 recE observed with pRC12 DNA is consistent with the finding that only subclones of $\mathrm{pRC} 12$ which lacked a functional spoIIA gene were capable of transforming strains of spoVA and spoIVA to Spo ${ }^{+}$. Possibly, multiple copies of this region of the spoIIA locus titrate essential sporulation regulatory proteins or lead to overproduction of critical sporulation gene products (Lovett, 1981).

Attempts to isolate sufficient amounts of purified and intact pRC12 DNA for physical and chemical studies were unsuccessful. The partially deleted molecules such as pRC12-5 are 
currently being used as probes with our genomic libraries in attempts to isolate recombinant clones with stable properties in the lys spoIIA-spoIVA region.

This work was supported by Public Health Service grants AI-10806 (to D. J.T.) and GM-18904 (to H. O. H.) from the National Institutes of Health. We express our gratitude to Swee Kee Wong for her excellent and devoted assistance and to $\mathrm{Dr} \mathrm{A}$. Wyman for providing the in vitro packaging strains.

\section{REFERENCES}

Aubert, E., FArgette, F., Foutt, A., KLier, A. \& RAPOPORT, G. (1982). Use of a bifunctional cosmid for cloning large DNA fragments of Bacillus subtilis. In Molecular Cloning and Gene Regulation in Bacilli, pp. 11-14. Edited by A. T. Ganesan, S. Chang \& J. A. Hoch. New York: Academic Press.

BANNER, D. C. (1980). Amplification in Bacillus subtilis of the promoter region of a cloned sporulation gene blocks development at an early stage. Abstracts of the American Society for Microbiology 197, 100.

Bonamy, C. \& Szulmaster, J. (1982). Cloning and expression of Bacillus subtilis spore genes. Molecular and General Genetics 188, 202-210.

BotT, K. F. \& WILson, G. A. (1968). Metabolic and nutritional factors influencing the development of competence for transfection of Bacillus subtilis. Bacteriological Reviews 32, 370-378.

DEAN, D. (1984). Molecular cloning of Bacillus subtilis genes and molecular cloning in $B$. subtilis. In Fundamental and Applied Aspects of Spores. Edited by G. J. Dring, I. J. Ellar \& G. W. Gould. New York: Academic Press (in the Press).

Dubnau, E., Ramakrishna, N., Cabane, K. \& Smith, I. (1981). Cloning of a sporulation gene in Bacillus subtilis. In Sporulation and Germination, pp. 104-108. Edited by H. S. Levinson, A. L. Sonenshein \& D. J. Tipper. Washington, D. C.: American Society for Microbiology.

Ferrari, E., Henner, D. J. \& Hoch, J. A. (1981). Isolation of Bacillus subtilis genes from a Charon 4A library. Journal of Bacteriology 146, 430-432.

HeNNER, D. \& HoCH, J. A. (1980). The Bacillus subtilis chromosome. Microbiological Reviews 44, 57-82.

HoHN, B. \& MURRaY, K. (1977). Packaging recombinant molecules into bacteriophage particles. Proceedings of the National Academy of Sciences of the United States of America 74, 3259-3267.

Holmes, D. \& QuigleY, M. (1981). A rapid boiling method for the preparation of bacterial plasmids. Analytical Biochemistry 114, 193-195.

Hutchinson, K. W. \& Halvorson, H. O. (1980). Cloning of randomly sheared fragments from a $\phi 105$ lysogen of Bacillus subtilis. Gene 8, 267-278.

Jenkinson, H. F. \& Mandelstam, J. (1983). Cloning of the Bacillus subtilis lys 3 and spoIIIB genes in phage $\phi 105$. Journal of General Microbiology 129, 22292240.

Karn, J., Brenner, S., Barnett, L. \& Cesareni, G. (1980). Novel bacteriophage $\lambda$ cloning vector. Proceedings of the National Academy of Sciences of the United States of America 77, 5172-5176.

KAVENOFF, R. (1972). Characterization of the Bacillus subtilis W23 genome by sedimentation. Journal of Molecular Biology 72, 801-806.

Kawamura, F., Shimotsu, H., Saito, N., Hirochika,
N. \& Kobayashi, Y. (1981). Cloning of spoO genes with bacteriophage and plasmid vectors. In Sporulation and Germination, pp. 109-113. Edited by H. S. Levinson, A. L. Sonenshein \& D. J. Tipper. Washington, D. C.: American Society for Microbiology.

LAZDIN, I. (1980). Partial purification of a restriction endonuclease fragment of Bacillus subtilis DNA containing the lysine and stage IIA sporulation genes. M.Sc. thesis, Ohio State University, U.S.A.

Lencastre, H. DE \& Piggot, P. J. (1979). Identification of different sites of expression for spo loci by transformation of Bacillus subtilis. Journal of General Microbiology 114, 377-389.

LiU, H.-M., ChaK, K. F. \& Piggot, P. J. (1982). Isolation and characterization of a recombinant plasmid carrying a functional part of the Bacillus subtilis spoIIA locus. Journal of General Microbiology 128, 2805-2812.

Losick, R. (1981). Sigma factor, stage 0 genes and sporulation. In Sporulation and Germination, pp. 4856. Edited by H. S. Levinson, A. L. Sonenshein \& D. J. Tipper. Washington, D. C.: American Society for Microbiology.

LovetT, P. S. (1981). Cloning strategies in Bacillus subtilis. In Sporulation and Germination, pp. 40-47. Edited by H. S. Levinson, A. L. Sonenshein \& D. J. Tipper. Washington, D. C.: American Society for Microbiology.

LOVETT, P. S. \& BRAMUCCI, M. G. (1974). Biochemical studies of two Bacillus pumilus plasmids. Journal of Bacteriology 120, 488-494.

MARMUR, J. (1961). A procedure for the isolation of DNA from micro-organisms. Journal of Molecular Biology 3, 208-218.

Piggot, P. J. \& CoOTE, J. G. (1976). Genetic aspects of bacterial endospore formation. Bacteriological $R e$ views 40, 908-962.

Primrose, S. B. \& Ehrlich, S. D. (1981). Isolation of plasmid deletion mutants and study of their instability. Plasmid 6, 193-201.

RAPOPORt, G., Klier, A., Billault, A., Fargette, F. \& DEDONDER, R. (1979). Construction of a colony bank of $E$. coli containing hybrid plasmids representative of the Bacillus subtilis 168 genome. Expression of functions harbored by the recombinant plasmids in B. subtilis. Molecular and General Genetics 176, 239-245.

TANaKa, T. \& SaKaguchi, K. (1978). Construction of recombinant plasmid DNA in Bacillus subtilis 168 composed of $\boldsymbol{B}$. subtilis leucine gene and a $\boldsymbol{B}$. subtilis (natto) plasmid. Molecular and General Genetics 165, 269-276.

Wensink, P., Finnegan, D., Donelson, J. \& HogNESS, S. (1974). A system for mapping DNA 
sequences in the chromosomes of Drosophila melanogaster. Cell 3, 315-325.

Yamare, K., Takeichi, Y., Masuela, F., Kawamura, F. \& SAITO, H. (1982). Construction and physical map of a Bacillus subtilis specialized transducing phage rholl containing the $B$. subtilis $\mathrm{Lys}^{+}$gene.
Journal of General and Applied Microbiology 28, 417429.

YudKIN, M. D. \& TURLEy, L. (1981). Mapping of six mutations in the spoIIA locus of Bacillus subtilis and studies of their response to a nonsense suppressor. Journal of General Microbiology 124, 255-261. 